\title{
State of the Art Research in the Judicialization of Politics
}

\section{Ary Jorge Aguiar Nogueira}

Pontifícia Universidade Católica do Rio de Janeiro (PUC-RIO), Rio de Janeiro, Brazil

Email: aryjorge.nogueira@hotmail.com

How to cite this paper: Nogueira, A. J. A. (2020). State of the Art Research in the Judicialization of Politics. Beijing Law Review, 11, 670-689.

https://doi.org/10.4236/blr.2020.113041

Received: June 11, 2020

Accepted: September 1, 2020

Published: September 4, 2020

Copyright $\odot 2020$ by author(s) and Scientific Research Publishing Inc. This work is licensed under the Creative Commons Attribution International License (CC BY 4.0).

http://creativecommons.org/licenses/by/4.0/

\begin{abstract}
Power expansion and judicial discourse in everyday life is now a global reality. The main objective of this article is to conduct a review of the judicialization of politics literature, presenting the state of the discipline. The methodology used includes a literature review of the main authors on the subject, with a compilation of key terms that correspond to this phenomenon. There are a range of invalid compilations on the topic and a lack of classical works publications, which merely reiterates why this article is highly relevant.
\end{abstract}

\section{Keywords}

Judicialization, Politics, State of the Art

\section{Introduction}

In recent decades, the world has experienced a new phenomenon without precedent, the expansion of judicial and legal discourse in all social relations. Courts are now called upon to resolve controversies that were previously seen as purely political. Every day, people resort to the judiciary to have their most basic needs met; the judicial form interferes throughout the public administration, so much so that the expression "administrative process" has become a common occurrence. Magistrates, who were traditionally a discreet social group, now occupy the media spotlight and are increasingly active in the feedback process.

It should be made clear that the choice has been made not to differentiate between the concepts of political and judicial activism, despite there being contradictory understandings duly pointed out in the body of the text. The main reason for this is because the vast majority of the literature makes no such distinction, mainly treating the terms as synonyms. This research intends to conduct an extensive review of the literature and to try to bridge the gap between the scarce amounts of material on the topic and review the judicialization of politics litera- 
ture, focusing on researchers who intend to open up new lines of research.

This article is divided into three parts. In the first part, the main definitions of judicialization are presented in chronological order. Subsequently, a history of the development of political judicialization, from neo-constitutionalism, with emphasis on new interpretative roles played by the American Supreme Court, a true paradigm for the other supreme courts, is outlined. Finally, a panorama of contemporary studies on political judicialization is presented.

\section{Definitions of Judicialization}

The verb "to judicialize", first appeared in the English language in the mid-19th century, meaning "to give judicial character"; "deliver to a judge the decision of" or "treat judicially". Judicialization, which is normally associated with the global expansion of the judiciary, presents an array of aspects which have been coined over time, using a range of different words. By rigorously reviewing the literature, we discovered eleven terms that maintain a similarity with the theme of judicialization: government of the judges; judicialization of political power; judiocracy; juridiciocracy; juridification; judiciarism; juridicization; government by the judiciary; judicial activism, political jurisprudence, and juristocracy.

The expression "government of judges" comes from the 1921 classic, Le Gouvernement des judges et la lutte contre la legislation sociale aux Etats-Unis, written by Edouard Lambert, who was a Professor of Law at Lyon, a specialist in comparative studies, and founder of the Lyon Institute of Comparative Law. In the debate regarding the convenience of completing the institutional framework of the Third French Republic, with the introduction of an branch with constitutional jurisdiction, the work emerges as a critical analysis of the constitutional justice of the United States.

This work is quoted a great deal, but has not been read much, this is probably due to the fact that the more popular the concept presented became, the more difficult it became to get a copy of the book ${ }^{1}$, which meant that Lambert's original concept became associated with a series of new meanings (Davis, 1987). In fact, the book has a straightforward argument, which is supported by a wide range of references. Its starting point was the development of a judicial review, which began in 1880 , when things progressed from a mere regulation of public powers separated for judgments about the adequacy of the legislation. The author describes the resistance of the US Supreme Court to social legislation, particularly the laws associated with compensation for employees and the labor legislation, Lochner Era ${ }^{2}$.

For Lambert, there were two developments underway, a noun and another ${ }^{1}$ To get a clear idea of how unavailable this book is, France only saw a new edition of the work in 2011, which was in fact a reprint of the original 1921 edition.

${ }^{2}$ The so-called Lochner Era was a period of United States legal history, which lasted, approximately, from 1905 until 1937, in which the Supreme Court declared the unconstitutionality of a series of state laws that dealt with economic regulation-particularly in regards to working conditions and the limitation working hours. It took its name from a precedent, the famous Lochner v. New York case in which the Supreme Court invalidated New York State legislation that sought to regulate the working day of bakers, under the argument that this regulation violated contractual freedom, seen as a right implicit in the Due Process Clause of the Fourth Amendment. 
procedure, which together have been crucial to the expansion of the American judicial review (Lambert, 1921: pp. 80-91). The first hoped that the due legal process had a compulsory substantive component, which would result in a large construction of rights to liberty, property, and contracts. Secondly, the North American techniques of building precedents were equally important, with the judgment of the courts replacing the Congress. The impotence of legislation led to legislative inactivity, which not only increased judiciary, but created a sense of public mistrust and hostility toward the figure of the judge.

However, its crucial declaration was the prediction that through the common law techniques of judgment, construction of statutes (infra-constitutional laws) and a substantive law, which elevated the individualism of social values, the judicial review could be extended, including the cancelation of constitutional amendments that attempted to limit their own judicial review. For Lambert, the judicial review of constitutional amendments was a potential threat, with the judiciary possibly controlling economic growth and social and political spheres without any resources (Lambert, 1921: pp. 109-113). That is why Lambert wrote about a "government" of judges, and it was only due to the fear of this threat, as the extrapolation of the judicial review could lead to a supreme judicial domination who could speak in a judicially ruled society. However, this situation was not only bound by North American conditions, but also by those inevitably conservative and ambitious of the law and of the legal profession.

The concept of judicialization of political power is well represented in Karl Loewenstein's (1955) Reflections on the Value of Constitutions in Our Revolutionary Age, a text that deals with the great constitutionalist movement that emerged after the end of the Second World War, which the author states as being "epidemic".

Loewenstein ascertains that the judicialization of political power efforts to tame the conflict of power, merely subject the political momentum to judicial decisions (Loewenstein, 1955: p. 217). However, it should be noted that Loewenstein does not defend the vulgarization of the procedure, and that the conflicts should be determined by exceptional standards. Otherwise, if the judicial powers of the constitution began to be used by various state agencies in competition for political power, for instance, the president against the government or parliament, the belief that the aspirations of power could be "decontaminated" by legal formulas constitute an over-taxation of the function of the judiciary. It is clearly outlined that in countries "older and wiser", the courts practice restraint when people refuse to overcome political issues or acts of government (Loewenstein, 1955: p. 217). Therefore, the author does not allude to the risks of the judiciary to exercise a more active stance, and the only danger of judicialization would be if this was somehow used as a weapon in the political dispute between the other powers of the state.

The expression judiocracy, appears in The Supreme Court and the People ar${ }^{3}$ The author points out that from 1945 to 1955 , more than fifty countries enacted new Constitutions (Loewenstein, 1955: p. 191). 
ticle, written in 1968 by Everett McKinley Dirksen, US Senator for the state of Illinois. According to Dirksen, the June 15, 1964, would have marked the end of the republican form of government in the United States of America, with the emergence of something different and incompatible with the concept of popular sovereignty. From this date, a series of cases, starting with Reynolds v. Sims , $^{\text {, }}$ were held in which the court assumed the authority which, until then, had purely been considered an inherent right to self-government.

Dirksen states that judiocracy is the process in which the Supreme Court would have made decisions regarding affirmation of the power of authority, which was previously people. In addition, the court would have turned their backs for more than two hundred years on historical and legal facts (Dirksen, 1968: p. 839). Therefore, it was a clear judicial intervention involving high politics (Hirschl, 2004), as it dealt with the notion of parliamentary representation and the possible affirmation of the judiciary to pose as a legitimate entity that could intervene and reconstruct the significance of the constitutional norm. Later it will be noted that the discussion about the limits of constitutional interpretation of the commandment by the judiciary will be highly relevant when looking at studies dealing with the phenomenon of judicialization.

The issue of training standards and constitutional interpretation seems to be inseparable from the increase of power in the judiciary. Karl Loewenstein (1979), in his theory of the Constitution ${ }^{5}$, presents the judiciocracy expression as the exacerbation of the judicialization of politics, with the installation of the court as a supreme arbiter of the process of power. Such a process would culminate in a governmental system dominated by judges.

For Karl Loewenstein, the teaching behind the processes of Weimar and Bonn $^{6}$, is that the process can only give certain guarantees when the conflict does not affect any vital interests of the holders of political power. When this process gives the courts the right to thwart a political decision made by the government or parliament, the potential threat that the decision of the court is not respected becomes apparent, which means that whatever threatens the rule of law, or the governments' policy decision, needs to be replaced by a judicial act that, even if ${ }^{4}$ Reynolds v. Sims was a case in which the United States Supreme Court decided that, unlike the election of the Federal Senate, on the election of any state legislature chamber, the electoral districts should be approximately equal in population (thus denying the traditional function of a State Senate, which was to allow the rural municipalities to counterbalance big cities). The case was submitted on behalf of the voters of Alabama by M.O. Sims, a taxpayer in Birmingham, Alabama, but affected both the north and the south, which also failed to reelect their legislatures after its implementation in five similar cases in Colorado, New York, Maryland, Virginia and Delaware.

${ }^{5}$ The original edition of the work is from 1957, under the title Political Power and the Governmentai Process, by the University of Chicago Press.

${ }^{6}$ Here, the author refers to two important stages in the formation of the modern German State: the German Republic founded in Weimar in 1918 by Scheidemann, which was in a weakened state from the beginning (Chacon, 1975): which was not only invaded by foreign troops, but divided by the constantly bickering factions of the extreme left and right, and that ended up, during the 1929 global crisis, suffering the mortal economic coup that allowed the rise of the Nazis; and the Republic of Bonn, which emerged from the Second World War, born under the auspices of the Marshall Plan and not under the yoke of the Treaty of Versailles, as was Weimar, and which allowed the German state to achieve a level of development that it still boasts about today. 
coated with legal and constitutional, is not pushed into the background, not a political act instigated by people who do not have any democratic mandate to carry out this function (Loewenstein, 1979: p. 325).

This is significantly different to Loewenstein's earlier understanding, who, in 1955, does not determine the judicialization of politics as something dangerous. Loewenstein asserts that the conflict between the idea of the rule of law and the right and duty of the government to govern would undermine both parties: quis custodiet custodes? (Loewenstein, 1979: p. 325).

Another important philosopher who has devoted his career to the study of the implications between the increase of the judiciary and the administration of the policy, is Jürgen Habermas. In the second volume of his work The Theory of Communicative Action, Habermas discusses what he calls the trends toward juridification (Habermas, 1986: p. 356).

According Habermas, the expression "juridification" (verrechtlichung ${ }^{8}$ ), generally refers to the trend toward an increase in formal law (or positive, writing), which can be observed in modern society. Habermas identifies four waves of juridification: the bourgeois states; the constitutional states; the democratic and constitutional democracy of social welfare (Habermas, 1986: p. 357).

During the formation of the bourgeois states the notion of civil society was built, whereby legal order was supposed to guarantee the freedom of individuals, the security of the law, the formal equality among all individuals before the law and thus, the possibility to calculate all actions legally established (Habermas, 1986: p. 358).

A second wave involves the constitutional regulation of the administrative authority, which until then, was limited and bound only by the legal form and the bureaucratic means of exercising power. The guarantees of life, liberty, and private property, have become a constitutional norm which has morally justified and marked the structure of political order (Habermas, 1986: pp. 359-360).

The Constitutional Democratic State took shape during the French Revolution. The power of the constitutional state was democratized: citizens, as citizens of the state, were ensured rights of political participation. The juridification, the process of legitimation, becomes entwined with general suffrage and equality, recognizing the freedom of the political organization of associations and parties (Habermas, 1986: p. 360).

For Habermas, the development toward this type of state can be understood as the institutionalization, in the legal form, of a social power anchored in the class structure. It would be a State in which the risks borne by the class structure would be offset by the implementation of a state bureaucracy focused on aspects that are not only therapeutic, but of their own monetary retribution (Habermas, 1986). Habermas did not unleash a Marxist approach to the question of the fund and its conception of verrechtlichung remains strongly associated with solidify${ }^{7}$ Who watches the watchmen?-our translation.

${ }^{8}$ verrechtlichung. judicialization and juridification. Though the translator of the most respected English version, Thomas McCarthy, has occasionally used the terms indistinctively, it is true that in the chapter where Habermas himself defines the meaning of verrechtlichung, all mentions of it use the term juridification (Habermas, 1986: pp. 332-373). 
ing the normative function of the State, with the notion that the strengthening of rights would imply an ever greater control of all aspects of daily life'.

Judiciarism is primarily discussed by two authors: Alan Pellet and Alain Lempereur. Alan Pellet (1988) is the author of The Normative Dilemma: Will and Consent in International Law-Making, while Alain Lempereur (1991) wrote Logic or Rhetoric in Law?

Pellet (1988: p. 29) focuses on international $\operatorname{law}^{10}$ and points to an apparent dilemma in international relations: the choice between accepting something as law by the will of the State (voluntarism) or what can be implemented judicially (judiciarism), i.e. could decisions by international courts be implemented with the same force as laws from individual states? If so, could the courts create policies from the understandings expressed in their decisions? For Lempereur (1991: p. 291), restricted judiciarism would be a source of standards, such as the natural law or the legislator. It would be the result of the discourse of judges, and act as an attempt to legitimize the decisions made.

Norbert Rouland (1994), in Legal Anthropology, punctuates juridicization as the process by which something becomes legal. It would be strongly associated with social regulation. Reich (1997: p. 777) states that juridicization derives from the word juridicus, which means or belongs to the courts or a legal system, and it also refers to the term jure gentium, "the law of nations". The term "legalization" would be less appropriate, as it would indicate the process of making something cool; in other words, make a phenomenon that was previously against the law legitimate. The author then focuses on international law and the growing intervention of judicial mechanisms in international relations.

Rosenfeld and Sajós (2012: p. 8), in turn, in The Oxford Handbook of Comparative Constitutional Law, discuss juridicization of constitutional laws and the fact that constitutional problems could be solved with adjudicatory tools of state law, especially when comparing constitutions, as this tool would consolidate itself as an autonomous discipline.

Therefore, the concept of juridicization is strongly linked to the role of interpreter of standards played by the judiciary, a movement in which not only standards, but the regulation of social life would be liable to be interpreted in the light of constitutional provisions. Later on, it will become clearer that this is one of the most relevant characteristics of the judicialization of politics.

Written in 1975 by Professor Raoul Berger, a Ukrainian who became a naturalized American, Government by Judiciary (2002) incorporated the idea initially launched by Lambert ${ }^{11}$, of a government in which the judiciary would occupy the highest position. The main thesis of the book (Berger, 2002: p. 401) is that the ${ }^{9}$ At this point it is impossible not to recall the biopolitics of Foucalt (2010: p. 393), understood to be the way it has been attempted, since the 18th century, to rationalize the problems created in the practice of government by specific population-related phenomena (health, hygiene, birth rate, longevity race).

${ }^{10}$ Something that had already been done by Stein (1981), however, without the manifestation of a specific concept of the phenomenon of judicial action as a formulator of policies.

${ }^{11}$ Although there is no quote attributed to the professor from Lyon, it must be emphasized that both books deal with the interpretive power of the US Supreme Court on constitutional amendments. 
Supreme Court would not be empowered to rewrite the constitution, which would have been done through the reinterpretation of the Fourteenth Amendment.

According to Berger, the first paragraph of the Fourteenth Amendment would not consider the right to vote as something protected by the equality of American citizens. Berger's main criticism is that the Supreme Court would not have been granted the power to formulate public policies and that the exercise of a broad interpretation of the rules outside the constitutional provisions would circumvent this seal, causing the judiciary to usurp the popular sovereignty. For Berger, if the maintenance of the democratic spirit depends on the formation of a government by the judiciary, this should be submitted for approval by the proprietor of the sovereignty, i.e. the people (Berger, 2002: p. 6612).

Although the term judicial activism has been circulating in American academic debates since mid-1937-1938 (Cover, 1982: p. 1289), it was in Central Europe and in Garapon's 1996 classic Le gardien des promesses. Justice et démocratie, that this expression won over the world. For Central Europe, judicial activism would become one of the most apparent symptoms of the weakening of the State (Garapon, 1996: p. 22), because judges could only occupy a place of prominence under the condition of finding a new political expectation that was not as satisfying as the traditional instances.

It can be seen that the french jurist uses the term as a synonym of judicialization, and cites a government of judges and judicial prominence as other possible meanings to the activism (Garapon, 1996: p. 54). It is also outlined that a contra role should be exercised by the judiciary, especially when the containment of democracy is that extreme (Garapon, 1996: pp. 199-218).

Political Jurisprudence written by Berkeley professor Martin Shapiro in 1963, brings the concept of political jurisprudence to the forefront, proposing that a new movement in legal theory would be in progress. This new movement would be characterized by the extension of certain elements of sociological jurisprudence and legal realism, combined with the substantive knowledge and methodology of science policy. Its foundation would be that the law should be understood not as an independent body, but as an integral part of the social system (Shapiro, 2002: pp. 282-283).

Shapiro also identifies a new understanding, consistent with American thought at the time, that judges would do more than simply discover the law. The core of the law policy would determine that political agencies and judges are political actors. This approach is similar to legal realism, whereby Shapiro himself recognizes it as positivist, in the sense that it intends to describe the political process, rather than prescribing how it should be (Shapiro, 2002: p. 759).

Exercises in the text are not a value judgment about this new approach, but recognize the practical limits and philosophical roots of political decisions (Shapiro, 2002: pp. 769-782). However, in 1999, Shapiro adopts a more optimistic standpoint about the role of the courts, especially in constitutional interpretation 
(Shapiro, 2002: pp. 2363-2380), pointing to the legislative inertia and the use of the court in contentious politics as a cause of great judicial prominence in recent decades.

Finally, the most cited author on the subject of judicialization is Ran Hirschl. His 2004 article, "Juristocracy" - Political, not Juridical, followed in 2006 by The New Constitution and the Judicialization of Pure Politics Worldwide, and his book Towards Juristocracy, in the same year, are the starting point for any researcher on the subject of expansion of the judiciary. The Neologism proposed by Hirschl (juristocracy) refers to the classic notion of the reign of the judges, and refers to the global trend to transfer an unprecedented amount of power of representative institutions to the judiciary, whether that be at a national or supra-national level (Hirschl, 2004).

According to Hirschl, one of the main manifestations of this trend has been the judicialization of politics, which, for the courts and judicial, means coping with moral dilemmas, public policy issues and political controversy. However, the growing political importance of the courts has not only become more comprehensive but has also expanded in scope, transforming it into a diverse, multifaceted phenomenon, which goes far beyond the concept of public policies formed by judges. The judicialization of politics now includes the mass transfer, for the courts, of some of the most prominent and controversial political controversies involving democracy (Hirschl, 2006b).

\section{Constitutionalism in Political Judicialization}

Judicialization cannot be thought of as dissociated from the advent of Liberal Constitutions and the consequent control of constitutionality of laws, which is then forced to change the role of the judge from being a mere annunciator of the law. It is important to remember that even in Roman Law there were serious restrictions on the judge's freedom of interpretation. For instance, Justinian's Digesto forbade its interpretation by the judges (Falcone, 2014: pp. 1-3).

The political institutions created by the constitution, from liberal inspiration, generally follow the lines advocated by Montesquieu in his treatise The Spirit of Laws, in Chapter VI, Book XI, on the separation of powers. For the French philosopher there would be no freedom if the judiciary is not separate from the legislature and the executive.

However, the separation of powers appears for the first time in England in the 17th century, with the rule of law of English law (Holdsworth, 1922). Contrary to the rule of law, it is preconceived by the legislator; the rule of law is the fruit of construction law, by means of historical values enshrined by society. In addition, it is true that in England in the 15th century the distinction between power of government (gubernaculum), established by King and jurisdictional power (iurisdictio), exercised by judges was already well known (Tavilla, 2013).

However, the strict separation of powers advocated by liberalism provides judges with a passive role, merely allowing them to use their mouths through 
which the words of the law are pronounced ${ }^{12}$.

Even one of the founding fathers of the United States, Thomas Paine, largely distrusted the role of the judiciary in government. It is well known that due to the assertion of Paine that a representative government equals freedom (Paine, 1817: p.52), but it is interesting to observe a representative governments critical bias about the need to separate acts of government acts of judicants, because according to Paine, when it comes to cases that apply to the nation as a whole, a jury of twelve people is not competent enough to decide (Paine, 1817: p. 9). Another founding father, Alexander Hamilton, highlighted the need for an independent judiciary for the maintenance of the constitution, demonstrating an apparent sympathy for the strengthening of the judiciary.

Either way, the country that the founding fathers created was responsible for a revolution which was extremely relevant and which lasted much longer than the mere separation of dominance: the judicial control of constitutionality.

The North American Judicial Review of Legislation has outlined the expansion of the role of the judge as interpreter of the law, leading not only to an increase in the judiciary, but to the fact that the United States occupies a peculiar home condition of judicialization (Shapiro, 2002: p. 728). In the 19th century the American model that inspired Tocqueville in his classic Democracy in America (1840), discussed the roles and the importance of the courts of that country.

Before proceeding any further, it should be noted that there is a specific European tradition of the judicial review, which also focuses on the control of constitutionality. It originated after the First World War, when Austrian Professor Hans Kelsen was entrusted with the task of drafting a constitution for the new Republic of Austria. In contrast to the American model, this Constitution ascertained that the review should not be dealt with by ordinary courts, but by a constitutional court, which was especially designed for this task (Kelsen, 1942). Kelsen implemented serious restrictions on the control of constitutionality exercised by judges, but did not show any fear toward the government of judges, believing that the worst that the judicial review could become would be unnecessarily politicized courts (Davis, 1987: p. 564). During the interwar period, this model was widely discussed and to a certain extent imitated outside of Austria. Brazil, for example, adopted a model that is neither entirely Kelsian, nor American. In Brazil there is a constitutional court, where it is not only the court itself but also the judges that exercise some type of control of constitutionality.

Returning to the North American model, the control of constitutionality of laws in the United States can be divided into four phases (Corwin, 1953): from 1801 to 1835, under the influence of Marshall, where the Supreme Court exercised judicial competence that was politically neutral, focusing on judicial control of federalism and the constitutionality of laws; from 1836 to 1894, important ${ }^{12}$ Sir Francis Bacon (Huycke, 1926: p. 625) categorically stated that judges should remember that their profession is "ius dicere" (speak the law) and not "ius dare" (provide the law). 
constitutional theories were formed as the substantive due process of $l a w^{13}$; from 1895 to 1937 control was expanded and the judges of the Supreme Court passed on control to the amendments to the constitution, with this era having the term government of judges by Lambert (1921) being widely known. During the fourth phase, which began in 1937, the court adopted a more incisive stance in defense of the powers of the government at the expense of the rights of individuals or of the Member States; this is the phase of the "constitution of powers", at the expense of the previous "constitution of rights" (Corwin, 1953).

It is the first stage of the famous case Marbury vs. Madison, in which the Supreme Court, guided by John Marshall, laid the foundations of the doctrine of political issues, which preaches no judicial intervention in the discretionary duties of senior government officials. This decision helped define the boundary between the executive and the judiciary.

It is a historic event which constitutes the basis for the exercise of judicial review in the United States, pursuant to Article 3 of the Constitution and originates from a petition to the Supreme Court by William Marbury, who had been appointed a justice of the peace in the District of Columbia by President John Adams (who was at the end of his mandate), but whose commission (somewhat equivalent to a term of investiture) was not delivered. When Thomas Jefferson was president, the new secretary of justice, James Madison, refused to name Marbury, who then asked the Supreme Court to determine that Madison should deliver the documents. The court, under the presidency of Marshall, acknowledged that the refusal of Madison was illegal. However, it was determined that to cease the mandamus under the allegation that the provision of the Law of 1789, which allowed Marbury to submit the request to the Supreme Court was unconstitutional, this was done by expanding the scope of Article 3 of the American Constitution. Consequently, the petition was denied.

With the death of Marshall in 1835, a new phase of the Supreme Court began under the chairmanship of Roger B. Taney. The supremacy of central government gives way to the dual concept of federalism, in which the powers of the Union and its Member States are understood to be equal and sovereign. In 1890, the Supreme Court applies the rule of reason to contain the imposition of tariffs not considered reasonable, applying substantive due process of law to the case of Chicago, Milwaukee \& St. Paul Railway Company v. Minnesota.

The case arose when a regulatory agency of Minnesota established rates of railroads that the Supreme Court of Minnesota refused to withdraw. When the company appealed to the Supreme Court, the court concluded that the rates were established without due legal process, specifically without the opportunity to contest the equality and reasonableness of the charges. The decision enabled the State to regulate the industry, but with limits on the due legal process. Although it already existed before 1890 (Paulsen, 1950), the idea of the substantive

${ }^{13}$ Due substantive process in American constitutional law, is a principle that allows the courts to protect certain fundamental rights of government interference. The basis of this protection stems from the interpretation of the Fifth and Fourteenth Amendments to the Constitution. 
due process of law gained strength around this time.

Furthermore, it should be noted that during this phase the Dred Scott v. Sanford case (1857), in which the court stated that a black man, whose ancestors were imported to the United States and sold as slaves, is either enslaved or free, outlining that an American citizen had no legitimacy to prosecute in federal court and that the federal government had no power to regulate slavery in the federal territories acquired after the creation of the United States. The decision written by Judge Roger B. Taney denied the request of Dred Scott, a black slave who wanted freedom. Although Taney thought that his decision would resolve the issue of slavery, it had the opposite effect and stimulated dissidence against anti-slavery in the north, and has proved to be an indirect catalyst for the American Civil War. This decision is considered by many as one of the worst to be handed down by the court (McCloskey, 1960: pp. 61-64).

Between 1895 and 1937, the court managed the due legal process noun more incisively, which allowed judges virtually unlimited control of laws, in defense of the rights of the citizen against the State. This moment was known as the Lochner Era and with it came, as we have already seen, the idea of the reign of the judges (Lambert, 1921). At this stage, the court assumes a combative stance in front of the New Deal and invalidates various laws, causing continuous criticism of the Roosevelt Administration (Rehnquist, 2007: pp. 130-131).

Re-elected with a large majority in 1936, Roosevelt finally achieved his goal of altering the social and economic legislation. During his presidency eight judges were appointed, a number that has not been achieved by any other president since George Washington (Rehnquist, 2007: pp. 146-147). In this period the Supreme Court became known as cutting of Roosevelt (Pritchett, 1948). From 1937 to 1946, the court had to adapt to the changing times of strong state intervention in the economy and centralized government.

Between 1946 and 1953, during the presidency of Vinson, the court adopted a conservative stance in line with the country's overall shift toward a posture of right (Galloway Jr., 1982: p. 376).

From 1954, with the leadership of Warren, the court begins to act decisively in the affirmation of civil liberties. During this period the Brown v. Board of Education of Topeka (1954) decision arose, it was a striking case in which the Supreme Court ruled the racial division between black and white students in public schools across the country as unconstitutional. This case reversed the decision made by the court in the Plessy v. Ferguson case (1896), which had become the legal basis to validate racial segregation in the United States in public places.

In the 1970s, in the Roe v. Wade case (1973), the court recognized, 7 to 2, abortion as a woman's right to privacy under the clause of due legal process. However, this right must be balanced with the interests of the State in the regulation of abortions: protect the health of women and protect the potentiality of human life. A decision can still be quite controversial even in the legal framework.

After several decades without a strong presence in the political sphere (Shapi- 
ro, 2002: p. 64), the Supreme Court has once again returned to the spotlight with the decision issued on 12 December 2000, in the Bush v. Gore case (2000). The court decided that there was a violation of the Equal Protection Clause when different patterns for counting votes in the state of Florida was used, but also determined that no alternative method could be used at that moment. After this decision, George W. Bush was declared the winner of the 25 electoral votes of Florida and consequently received 271 votes in the electoral college, which earned him the victory in the race for the presidency. This particular decision is controversial and still raises some big questions, especially regarding the integrity of that election (Norris, 2014: p. 97).

Another decision which had great repercussions for policies adopted by the Supreme Court was the Hamdan v. Rumsfeld case, in which the Supreme Court of the United States determined that the military commissions created by the Bush government to hold and investigate detainees at Guantanamo Bay could no longer operate because its structure and procedures both violated the Uniform Code of Military Justice of the Geneva Convention signed in 1949.

In the next section, we will determine how the issue of expansion of activity and of the judiciary is being discussed today, as well look at how the modern concept of judicialization of politics has been formed.

\section{Contemporary Studies of Political Judicialization}

Previously, it was outlined that political judicialization could not be considered without the advent of Liberal Constitutions and the development of the system of judicial review of laws and administrative acts. However, it should be mentioned that an important component in the increment of the judiciary arose because of neo-constitutionalism (Stone Sweet, 2000; Hirschl, 2006a, 2006b), a movement that is distinguished from the Anglo-Saxon tradition whose roots are found in the medieval period and also the constitutional regimes of the 1800 s (Mcilwain, 1940).

Regarding the purpose of the constitutional question, Sunstein (2005) points out that four approaches dominate the discussion: perfectionism; majoritarianism; minimalism; and fundamentalism. The perfectionist wants to make the constitution the best it can be. For majoritarians, the Supreme Court should reserve deference in relation to the decisions of democratically elected representatives. Minimalists are skeptical about general theories of interpretation and intend to proceed one step at a time; insisting that the constitution is not frozen in time, but are critical of the interpretative excesses of judges. Fundamentalists believe that the constitution should be interpreted in accordance with the original understanding.

However, according to Cover (1982: p. 1289), terms regarding modern debates about judicial activism were generated in the context of both the New Deal American and as a totalitarianism abroad in 1937-1938. Currently, the American Supreme Court regularly reviews the legislation in favor of the principles of per- 
sonal rights.

This shift began during the United States v. Carolene Products Co. case, when the decision was issued on April 25, 1938. This case is famous for its Footnote Four, in which the court established a more rigorous analysis system of laws aimed at "discrete and insular minorities", in comparison to the lowest vote applied to economic regulations.

The judicialization of politics, a phenomenon that Pildes (2004: p. 2) also called "Constitutionalization of democratic politics", has now spread across the world after initially sweeping across the western world in the last 30 years, with the principle of constitutional supremacy as a pillar of the political order finally becoming mainstream (Hirschl, 2006b).

According to Guarnieri and Pederzoli, (2017: p. 21), this new constitutionalism can be understood as a complex range of principles and instruments that help to moderate the exercise of political power, stopping any possible excesses of the majority government and alleviating democracy itself, ultimately, with the aim to protect freedom, especially the individual's freedom.

Guarnieri and Pederzoli also propose an interesting typology on the role of the judiciary, associating political autonomy and creativity in the form of a matrix (Guarnieri \& Pederzoli, 2017: p. 163).

Guarnieri and Pederzoli present models that represent the extremes of each type of attitude. In the context of a high degree of political autonomy, judges with greater creativity could give rise to the figure of the activist judge, which is merely another type of political actor. Although, the utmost restraint could provide an opportunity to judge them, high levels of creativity with little political autonomy can lead to the pursuit of a type of creativity that is free of political interference, while a low level of creativity with low autonomy can result in the classical figure of the judge as the "mouth of the law", i.e. the magistrate who has no freedom to interpret the norm.

The most widespread concept of judicialization of politics was elaborated by Torbjörn Vallinder (1995), and comprises of 1) the expansion of the courts or judges at the expense of politicians and/or administrators, i.e. the transfer of rights of decision of the legislature, the office, or the public service to the courts; or 2) the dissemination of judicial methods of decision-making outside the judicial area itself. In summary, the judicialization essentially involves transforming something into the form of a judicial process (Vallinder, 1995: p. 13).

Vallinder also points out that there would be two forms of judicialization: from without and from within. While the first would be the most appropriate judicial review, the second would be the introduction or expansion of staff from the judiciary or methods of judicial work in the administrative sector (Vallinder, 1995: pp. 15-16).

C. Neal Tate (1995) points out that there would be some enabling conditions for the expansion of the judiciary: the presence of democracy, a system of separation of powers, a policy of rights, a system of interest groups and a political opposition aware of the judicial means to achieve their interests, broken, weak or 
fragile government coalitions in majority institutions leading to political deadlock, inadequate public support, at least in relation to the judiciary, and the delegation to courts of the decision-making authority in certain policy areas (Tate, 1995: pp. 28-32).

However, Tate states that even under a very favorable constellation of Facilitative Conditions, the actual development of the judicialization of politics requires that judges have attitudes and preferences that are considered appropriate, especially in relation to the values of other decision-makers. Under another favorable condition, judicialization develops if judges decide who should 1) participate in the preparation of policies and, at least occasionally, and 2) replace the political solutions that derived from other institutions (Tate, 1995: p. 33).

However, there are authors who associate the increase in litigation with the increase in legal culture, which is the set of guidelines that shape a pattern of attitudes toward the right, with the State producing, applying, violating or guaranteeing the rights (Santos, Marques, \& Pedroso, 1996: p. 38). Judicialization would, therefore, be a side effect of the expansion of citizenship itself.

In recent years this phenomenon has spread throughout the world. Today, there is solid work covering judicialization in Latin America (Sieder, Schjolden, \& Angell, 2016), in post-Soviet republics (Thomas, 1995; Kitchin, 1995; Mazmanyan, 2015) and to the east (Mccargo, 2014; He, 2013; Matsudaira, 2010).

John Ferejohn (2002) suggests two general causes of judicialization. The first is an increase in the fragmentation of power within the political branches, which can limit the ability of the legislature to legislate or be the place where the policy is effectively formulated. It is the hypothesis of fragmentation (Ferejohn, 2002: p. 55). When politicians are unable to act, the people who seek a resolution of these conflicts tend to gravitate toward the institutions which can provide them with adequate solutions. Places that are associated with the courts and aware of the legal processes can often provide such solutions, even tackling unpopular policies.

The second cause is much more nebulous, but more important. The courts (at least certain courts) can be trusted to protect a wide range of important values against potential abuses by politicians. Ferejohn calls this a hypothesis of rights (Ferejohn, 2002: pp. 55-56). Whereby, courts protect people's rights and personal freedoms, as well as property rights, in opposition to the expansive judicial role that has decreased. However, this phenomenon is not immune to criticism.

According to Sieder \& Angell (2016: pp. 206-209), "judicialized politics” would raise fundamental issues about the appropriate balance of power and responsibility between representative bodies and elected and appointed members of the judiciary. Important decisions involving constitutional interpretation would be taken by constitutional courts, with widespread implications for the nature of politics and policy.

Hirschl (2006a: pp. 723-724) highlights that the judicialization of politics is confused with a generic version of judicial activism, paying little attention to the difference between assigning to courts the definition of what is meant as a fair 
trial, and entrusting them with a solution to delicate issues of collective identity, involving the construction of the nation.

For Hirschl, there are three broad categories of judicialization: the dissemination of speeches, jargon, legal rules and procedures in the political sphere, and the fora and processes of elaboration of public policies; the judicialization of the formulation of public policies by "ordinary" forms of judicial control of constitutionality of laws and acts of public administration; and the judicialization of politics as "pure", i.e. the transfer to the courts, whose nature and significance are intertwined with politicians, including debates on the legitimacy of regimes and collective identities that define or divide, whole communities (Hirschl, 2006a: pp. 722-723).

For Hirschl, everything can be judicialized (Hirschl, 2004: p. 6), but it is also political (Hirschl, 2004: p. 7). The wave of judicial activism that has swept the world in recent decades did not circumvent the more fundamental questions that a democratic policy should address, for example, dilemmas relating to cultural identity. According to Hirschl (2004: p. 7), none of these issues are exclusive or intrinsically legal, although some have important constitutional aspects. However, they are not purely, or even primarily, legal dilemmas. Therefore, they should be solved, at least in principle, through public deliberation in the political sphere. Though, national courts throughout the world have become larger decision-makers and bodies that deal with all of these dilemmas.

Hirschl (2004: p. 8) states that judicial activism can also emanate from a political issue arising out of a weak, decentralized or chronically blocked political system. Thus, the more dysfunctional the political system is in a democracy, there is a greater chance of an expansion of judicial power involving that policy. The persistent policy deference to the judiciary can be an effective way to overcome the "ungovernability" policy and guarantee the unity and the "normality" of such policies. The structural inability of the policy to deal with social and cultural rights, and the impasse faced by the majority of the policy, means that this policy needs to erode the authority of the legislative and executive branches of the government, thus leading to a systemic dependence of decision-making training and purportedly apolitical agencies such as the constitutional courts. Moreover, courts and governmental agencies are subject to the same political inflows, something which had not yet developed in Brazil, something which has already been mentioned and is highly postulated by Shapiro (2002: pp. 307-310).

Political judicialization seems to offer a convenient refuge to politicians who seek to avoid difficult political decisions. Thus, when issues of political disputes are treated as legal issues, the concomitant assumption of judges and courts at the expense of elected representatives in arenas of decision/policy formulation could solve this problem (Hirschl, 2006b: p. 213). In fact, judicial endorsement could even help legitimize controversial political decisions (Kapiszewski et al., 2013: p. 406).

The main criticism of the judicialization of politics and judicial activism is usually in three different fields (Santos, Marques, \& Pedroso, 1996): in the field 
of legitimacy, capacity and independence. The question of legitimacy concerns the formation of the will of the majority, i.e. that the path of political representation is obtained at the polls. As the judiciary, as a rule, does not have elected members, does the democratic content of a judicial intervention originate elsewhere? Regarding capacity, it is unclear whether the judiciary would be effective, providing the necessary resources to comply with decisions. As most of the time, the judiciary depends on other sectors of the public administration to carry out measures, with critics pointing out that the judiciary would depend on the goodwill of others.

Finally, as regards independence, this could be split into two symmetrical biases: legitimacy and capacity. At first, criticism arises whenever the other powers adopt measures that could damage their independence. Regarding capacity, the lack of financial and administrative autonomy to obtain the resources needed for proper functioning is what causes most problems.

But the most incisive criticism of the new constitutionalism and its main effect, the judicialization of politics, comes from Michael Mandel (1998: pp. 252-253), who determines that the judicial review is not the essence but the opposite of democracy, and not only in the sense that non-elected people (judges) would be annulling elected legislatures. For Mandel, it would be merely a symptom of the problem. The new constitutionalism was designed to operate and function as an antidote to democracy, to preserve the oligarchies of the private property of the mortal danger represented by representative institutions elected by people without properties. While the representative institutions constituted a monopoly of these oligarchies, through limitations on suffrage or other devices, theorists began to praise parliamentary sovereignty. But from the moment in which the proprietary classes lost control of these institutions, usually as a result of having to grant a right of suffrage more broadly, the same constitutional theorists began to worry about the alleged "tyranny of the majority" (curiously, few were concerned with the tyranny of the minority). Then came the solution of a judicial review, as a way to change everything (i.e. the constitutional theory) and ensure that everything (i.e. the oligarchy of the rich) remained the same way (Mandel, 1998). Limits were then placed on to the actions of the government and the legal class was invited to police these limits.

Recently, Brinks, and Blass (2017) proposed a reconceptualization of judicial power, trying to overcome the mere question of "independence". At the time, based on the concepts of principal-agent theory, Brinks and Blass identified two primary dimensions of judicial empowerment: autonomy (the policy affecting the court) and authority (the court affecting the policy).

Thus, when courts have a broad authority but low autonomy, constitutional justice channels the majority policy and reinforces the goals of the scheme that is submitted. If, in addition to low autonomy, the authority is limited or narrow, constitutional justice becomes largely irrelevant to the policy (Brinks \& Blass, 2017: pp. 8-9).

On the other side of the matrix, it is observed that in addition to more au- 
tonomy, the courts relying on broad authority will become the largest formulators of public policies, and the many versions of the High Constitutional justice will permeate the policy. Finally, if the autonomy is high, but the authority is limited, the courts only monitor the fundamental rights, with the constitutional justice being limited to protect the market and the political process (Brinks \& Blass, 2017: pp. 8-9).

The Brinks and Blass's model has certain similarities to that proposed by Guarnieri and Pederzoli (2017) $)^{14}$, especially when comparing the different types of constitutional justice with the different types of constitutional affairs that have arisen over the years. Guarnieri and Pederzoli present a slightly more optimistic version of the expansion of the judiciary by asserting that more countries are abandoning the old model, where the courts and the law were linked to the exercise of political power. A state based on law, with autonomous courts, could reduce arbitrary action, impose certain disciplines and predictability, as well as create openings for the less powerful in society (Brinks \& Blass, 2017: p. 38).

The politics of juridification is incorporated by Mariano Croce (2018) conceptualizing it in a broader sense, than merely intensifying people's access to legal help. For Croce, juridification far exceeds the expansion of legal competence in the channeling of social change or the transfer of authority to the judicial institutions. Through this there would be a purely institutional process of expansion in the scope of legal bodies and the redistribution of powers and authority. It would in fact be synonymous with Hirschl's judicialization and would consist of the expansion not only of the judiciary, but also of this modality and discourse in social life, with the judiciary being sued to solve political issues.

\section{Final Considerations}

The expansion of the judiciary is an indisputable fact and once implemented there is no turning back. Apparently, the political reality and normativity of law have become unified by new constitutional systematics. The most incisive performance of judges, particularly in the Supreme Court, seems to constitute a new legal paradigm. It should be remembered that a presidential election in the not so distant past had its outcome decided by the Supreme Court.

Political judicialization is a multifaceted phenomenon and therefore requires multiple study approaches. Neo-constitutionalism and its developments have resulted in the expansion of the judiciary, and every day the courts occupy more space in the political news, the consequences of which are still not completely consolidated. It is true that the phenomenon of judiciary expansion is not immune to criticism and only time will tell whether the consequences of this new activism will be positive or not.

With the development of an empirical research agenda in law, the methodological links between the law and political science should strengthen over the coming years, requiring new theories and hypotheses to be formulated so as to

${ }^{14}$ Although the work of Brinks and Blass took place prior to that of Guarnieri and Pederzoli, they did not make any reference to their predecessors. 
address an increasingly complex reality. Hopefully, this article contributes to the improvement of this new academic reality.

\section{Conflicts of Interest}

The author declares no conflicts of interest regarding the publication of this paper.

\section{References}

Berger, R. (2002). Government by Judiciary (2nd ed.). Indianapolis, IN: Liberty Fund.

Brinks, D. M., \& Blass, A. (2017). Rethinking Judicial Empowerment: The New Foundations of Constitutional Justice. International Journal of Constitutional Law, 15, 296-331. https://doi.org/10.1093/icon/mox045

Chacon, V. A. (1975). República de Weimar e a República de Bonn. Brasília: Revista de Informação Legislativa.

Corwin, E. (1953). The Constitution of the United States of America, Analysis and Interpretation. US Government Printing Office.

Cover, R. M. (1982). The Origins of Judicial Activism in the Protection of Minorities. The Yale Law Journal, 91, 1287-1316. https://doi.org/10.2307/795956

Croce, M. (2018). The Politics of Juridification. London: Routledge. https://doi.org/10.4324/9781315795720

Davis, M. H. (1987). A Government of Judges: An Historical Review. The American Journal of Comparative Law, 35, 559-580. https://doi.org/10.2307/840481

Dirksen, E. M. (1968). The Supreme Court and the People. Michigan Law Review, 66, 837-874. https://doi.org/10.2307/1287183

Falcone, G. (2014). The Prohibition of Commentaries to the Digest and the Antecessorial Literature. Subseciva Groningana, 9, 1-36.

Ferejohn, J. (2002). Judicializing Politics, Politicizing Law. Law and Contemporary Problems, 65, 41-68. https://doi.org/10.2307/1192402

Foucalt, M. (2010). Nascimento da Biopolítica. Lisboa: Edições 70.

Galloway Jr., \& R. W. (1982). The Vinson Court: Polarization (1946-1949) and Conservative Dominance (1949-1953). Santa Clara Law Review, 22, 375.

Garapon, A. (1996). Gardien des promesses (Le): Justice et Démocratie. Odile Jacob.

Guarnieri, C., \& Pederzoli, P. (2017). Il sistema giudiziario. Bologna: Il Mulino.

Habermas, J. (1986). The Theory of Communicative Action. A Critique of Functionalist Reason, Vol. 2. Boston, MA: Beacon Press Books.

He, X. (2013). Judicial Innovation and Local Politics: Judicialization of Administrative Governance in East China. The China Journal, 69, 20-42.

https://doi.org/10.1086/668805

Hirschl, R. (2004). "Juristocracy”-Political, Not Juridical. The Good Society, 13, 6-11. https://doi.org/10.1353/gso.2005.0020

Hirschl, R. (2006a). The New Constitutionalism and the Judicialization of Pure Politics Worldwide. Fordham Law Review, 75, 721.

Hirschl, R. (2006b). Towards Juristocracy: The Origins and Consequences of the New Constitutionalism. Cambridge, MA: Harvard University Press.

Holdsworth, W. S. (1922). A History of English Law. London: Methuen. 
Huycke, E. (1926). Francis Bacon. The Canadian Bar Review, 4, 625.

Kapiszewski, D. et al. (2013). Consequential Courts: Judicial Roles in Global Perspective. Cambridge: Cambridge University Press. https://doi.org/10.1017/CBO9781139207843

Kelsen, H. (1942). Judicial Review of Legislation: A Comparative Study of the Austrian and the American Constitution. The Journal of Politics, 4, 183-200. https://doi.org/10.2307/2125770

Kitchin, W. (1995). Legal Reform and the Expansion of Judicial Power in Russia. In C. N. Tate, \& T. Vallinder (Eds.), The Global Expansion of Judicial Power (pp. 441-461). New York: NYU Press.

Lambert, E. (1921). Le Gouvernement des juges et la lutte contre la législation sociale aux États-Unis, l'expérience américaine du contrôle judiciaire de la constitutionnalité des lois. Paris: Marcel Giard.

Lempereur, A. (1991). Logic or Rhetoric in Law? Argumentation, 5, 283-297. https://doi.org/10.1007/BF00128812

Loewenstein, K. (1955). Reflections on the Value of Constitutions in Our Revolutionary Age. In Constitutions and Constitutional Trends since World War II (2nd ed., vol. 2, pp. 203-206). New York: New York University Press.

Loewenstein, K. (1979). Teoría de la Constitución. Barcelona: Editora Ariel.

Mandel, M. (1998). A Brief History of the New Constitutionalism, or "How We Changed Everything So That Everything Would Remain the Same”. Israel Law Review, 32, 250-300. https://doi.org/10.1017/S0021223700015661

Matsudaira, T. (2010). Judicialization of Politics and the Japanese Supreme Court. Washington University Law Review, 88, 1559.

Mazmanyan, A. (2015). Judicialization of Politics: The Post-Soviet Way. International Journal of Constitutional Law, 3, 200-218. https://doi.org/10.1093/icon/mov003

Mccargo, D. (2014). Competing Notions of Judicialization in Thailand. Contemporary Southeast Asia: A Journal of International and Strategic Affairs, 36, 417-441. https://doi.org/10.1355/cs36-3d

McCloskey, R. G. (1960). The American Supreme Court. Imprenta: Chicago, University of Chicago Press.

Mcilwain, C. H. (1940). Constitutionalism: Ancient and Modern. Clark, NJ: The Lawbook Exchange, Ltd.

Norris, P. (2014). Why Electoral Integrity Matters. Cambridge: Cambridge University Press. https://doi.org/10.1017/CBO9781107280861

Paine, T. (1817). The Rights of Man. London: W. T. Sherwin.

Paulsen, M. G. (1950). The Persistence of Substantive Due Process in the States. Minnesota Law Review, 34, 91.

Pellet, A. (1988). The Normative Dilemma: Will and Consent in International Law-Making. Australian Year Book of International Law, 12, 22. https://doi.org/10.1163/26660229-012-01-900000005

Pildes, R. H. (2004). The Constitutionalization of Democratic Politics. Harvard Law Review, 118, 29.

Pritchett, C. H. (1948). VI. The Roosevelt Court: Votes and Values. American Political Science Review, 42, 53-67. https://doi.org/10.2307/1949461

Rehnquist, W. H. (2007). The Supreme Court. Vintage.

Reich, A. (1997). From Diplomacy to Law: The Juridicization of International Trade Relations. Northwestern Journal of International Law \& Business, 17, 777. 
Rosenfeld, M., \& Sajó, A. (2012). The Oxford Handbook of Comparative Constitutional Law. Oxford: Oxford University Press. https://doi.org/10.1093/oxfordhb/9780199578610.001.0001

Rouland, N. (1994). Legal Anthropology. London: The Athlone Press.

Santos, B. S., Marques, M. M. L., \& Pedroso, J. (1996). Os tribunais nas sociedades contemporâneas. Revista Brasileira de Ciências Sociais, 30, 29-61.

Shapiro, M. (2002). Political Jurisprudence. In M. Shapiro, \& A. S. Sweet (Eds.), On Law, Politics, and Judicialization (pp. 281-781, Electronic Edition-Kindle). Oxford: Oxford University Press. https://doi.org/10.1093/0199256489.003.0001

Sieder, R., Schjolden, L., \& Angell, A. (2016). The Judicialization of Politics in Latin America. New York: Springer.

Stein, E. (1981). Lawyers, Judges, and the Making of a Transnational Constitution. American Journal of International Law, 75, 1-27. https://doi.org/10.2307/2201413

Stone Sweet, A. (2000). Governing with Judges: Constitutional Politics in Europe. Oxford: Oxford University Press.

Sunstein, C. R. (2005). Radicals in Robes: Why Extreme Right-Wing Judges Are Wrong for America. Chicago: The University of Chicago, Public Law Working Paper, Cass Sunstein.

Tate, C. N. (1995). Why the Expansion of Judicial Power? In C. N. Tate, \& T. Vallinder (Eds.), The Global Expansion of Judicial Power (pp. 27-39). New York: NYU Press.

Tavilla, E. (2013). Sovranità e leggi fondamentali: Alla ricerca di una dimensione costituzionale nell'Europa moderna (secc. XV-XVIII). Journal of Constitutional History/Giornale di. Storia Costituzionale, 25.

Thomas, C. A. (1995). The Attempt to Institute Judicial Review in the Former USSR. In C. Neal Tate, \& T. Vallinder (Ed.), The Global Expansion of Judicial Power. New York: NYU Press.

Vallinder, T. (1995). When the Courts Go Marching. In C. N. Tate, \& T. Vallinder (Eds.), The Global Expansion of Judicial Power (pp. 13-26). New York: NYU Press. 